\title{
Antioxidant Activity, Carbohydrates and Protein in Sorgum (Sorghum bicolor L. Moench) Plants as a Development of Economic Functional Food Materials During The COVID-19 Pandemic
}

\author{
Ni Wayan Sukma Antari \\ Institute of Technology and Health Bali, Indonesia \\ Corresponding author email: sukma.antari91@gmail.com \\ Ida Ayu Manik Damayanti \\ Institute of Technology and Health Bali, Indonesia \\ Nadya Treesna Wulansari \\ Institute of Technology and Health Bali, Indonesia
}

\begin{abstract}
This study aims to determine the content of antioxidants, carbohydrates, and protein in Sorghum (Sorghum bicolor L. Moench) as an economically functional food ingredient during the COVID-19 pandemic. The research stages include the manufacture of sorghum seed extract, Antioxidant level testing using the DPPH test, carbohydrate content testing, and protein content determination using the Kjeldahl method, the Kjeldahl method consists of 3 stages, namely: the destruction stage, the distillation stage, and the titration stage. The results showed that Sorghum had an IC50 value of 88.8970 ppm, carbohydrate content of $71.8 \mathrm{~g}$, and protein content of $9.68 \%$. so that sorghum has the potential to develop functional food during the COVID-19 pandemic.
\end{abstract}

Keywords---antioxidants, carbohydrates, protein, Sorghum bicolor L. Moench

\section{Introduction}

The COVID-19 pandemic not only has an impact on public health, but also affects the economic conditions, education, and social life of the Indonesian people. The outbreak of the COVID-19 pandemic virus. On March 11, 2020, the World Health Organization categorized COVID-19 as a pandemic, where its spread made WHO declares an emergency and classified it as a chronic pandemic (WHO, 2020). The condition of the COVID-19 pandemic has suppressed global economic growth and has had social and economic impacts, especially in the agricultural sector., April 2020) therefore the agricultural sector has begun to be developed by the government to support economic development in Indonesia (Berenguer \& Faci, 2001; Farré \& Faci, 2006).

Indonesia is a country that has abundant sources of food wealth, in the field of agriculture many new varieties have emerged and had high economic value, one of the developments in agriculture that is currently developing is sorghum (Sorghum bicolor L. Moench) grain. The use of sorghum as a source of functional food has not been widely touched, so far it is still limited to its role in food diversification as a food source (Suarni, 2016). Whereas sorghum contains dietary fiber that the body needs (dietary fiber) which can have a positive effect on health. Health benefits, especially for the prevention of heart disease, obesity, reducing hypertension, maintaining blood sugar levels, and preventing colon cancer (Mupangwa et al., 2012; Sharanagat et al., 2019).

The potential of sorghum in Indonesia is quite large with a variety of varieties, both local and introduced, but its development is not easy. Many problems are faced including social, cultural, and psychological where rice is a prestigious food (superior food) while sorghum is less prestigious (inferior food), whole wheat is a very prestigious imported food ingredient (Patel \& Trivedi, 2016; Wiwekowati et al., 2017). Sorghum is a complementary food ingredient for rice which has a comparative advantage over other cereals such as corn, wheat, and rice. Antioxidants 
in food play an important role in maintaining product quality, preventing rancidity, changes in nutritional value, changes in color and aroma, and other physical damage caused by oxidation reactions (Dewi et al., 2012). The antioxidants produced by the human body are not enough to fight free radicals, for that the body needs an intake of antioxidants from outside. From the explanation above, it is necessary to conduct research that aims to determine the content of antioxidants, carbohydrates, and protein in Sorghum (Sorghum bicolor L. Moench) as an economical functional food during the COVID-19 pandemic (Sudarmadji et al., 1989; Yen \& Chen, 1995).

\section{Methods}

This type of research is experimental. The research stages are making sorghum seed extract, testing for antioxidant levels using the DPPH test, testing for carbohydrates, and determining protein levels using the Kjeldahl method, the Kjeldahl method consists of 3 stages, namely: the destruction stage, the distillation stage, and the titration stage.

\section{Results}

Sorghum has a high antioxidant test compared to corn. This shows that sorghum has strong free radical scavenging activity. Free radicals are compounds or molecules that contain one or more unpaired electrons in their outer orbitals (Moraes et al., 2015; Dlamini et al., 2007). The presence of unpaired electrons causes these compounds to be very reactive looking for partners, by attacking and binding electrons to molecules in the vicinity. Antioxidants are electron-donating compounds or reductants. This compound has a small molecular weight but can inactivate the development of oxidation reactions, by preventing the formation of radicals (Werdhasari, 2014). Antioxidants are also compounds that can inhibit oxidation reactions, by binding free radicals and highly reactive molecules, so that cell damage will be inhibited (Winarsi, 2007). Therefore, it is necessary to eat foods or foods that contain strong levels of antioxidants.

Table 1

The IC50 value of sorghum and corn extract

\begin{tabular}{ll}
\hline Samples & $\mathrm{IC}_{50}(\mathrm{ppm})$ \\
\hline Sorghum & 88.8970 \\
Corn & 78.6790 \\
\hline
\end{tabular}

The effectiveness of a sample to scavenge free radicals from the DPPH method is named IC50. The definition of IC50 is a concentration that can reduce 50\% of DPPH free radicals. The smaller the IC50 value, the greater the antioxidant activity. A compound is said to have very strong antioxidant activity if the IC50 value is less than 50 ppm, a strong group IC50 is between 50-100 ppm, a moderate group if the IC50 value is 101-150 ppm, and a weak group if the IC50 value is between 150-200 ppm (Molyneux, 2003, 2004). From the results of Table 1. The IC50 value in sorghum is $88.8970 \mathrm{ppm}$, and corn is 78.6790 including strong antioxidant activity.

The carbohydrate content of sorghum is lower than that of corn. The low carbohydrate content of sorghum will be safe for consumption for patients suffering from degenerative diseases such as diabetes. Diets rich in fiber and low in carbohydrates are very effective in diabetics to prevent increased insulin levels in the blood, according to Santoso (2011). Sorghum has a low glycemic index of 44.69 so it is good for diabetics, as well as for healthy people who use it. prevent diabetes (Werdhasari, 2014). The basic nutrition of sorghum is not much different from other cereals. From the results of the study, the protein content of sorghum was higher than that of corn.

Table 2

The value carbohydrate content of sorghum and corn (g)

\begin{tabular}{lll}
\hline Samples & Research Results $(\mathrm{g})$ & Based on research literature $(\mathrm{g})$ \\
\hline Sorghum & 7.8 & 70.7 \\
Corn & 73.6 & 73.0 \\
\hline
\end{tabular}

Table 2. shows the results of the carbohydrate content of the research results in sorghum at $71.8 \mathrm{~g}$ and in corn at $73.6 \mathrm{~g}$, these results are not significantly different from the carbohydrate content from the literature (Source: 
Directorate of Nutrition, Ministry of Health, Indonesia) (do Prado et al., 2019; Dykes \& Rooney, 2006). The carbohydrate content of sorghum is lower than that of corn.

Table 3

The value protein content of sorghum and corn (\%)

\begin{tabular}{lll}
\hline Samples & Research Results $(\%)$ & Based on research literature $(\%)$ \\
\hline Sorghum & 9.68 & 10.40 \\
Corn & 8.02 & 9.02 \\
\hline
\end{tabular}

Table 3. shows the results of the protein content of the research results on sorghum and corn of 9.68, and corn of 8.02. these results were not significantly different from the protein content of the literature (Source: Directorate of Nutrition, Ministry of Health, Indonesia (1992)) (Yousif et al., 2012; Luzardo-Ocampo et al., 2020). The protein content of sorghum is lower than that of corn. Sorghum can be used as a functional crop substitute for rice and corn because its lower carbohydrate content and higher protein content make it potential to grow and become of higher economic value. How to plant sorghum is relatively easy and does not require a lot of water, because sorghum can live even in dry places (Sisein, 2014; Andriani \& Isnaini, 2013).

In Indonesia, the harvested area of sorghum in 1990-2010 was only about 25,000 ha and spread, so it was not included in the FAO statistical list. Sorghum crops in Indonesia are pressured by valuable commodities such as rice, corn, coconut, and other valuable food crops. The potential of sorghum as a functional crop in the pandemic era can be a solution to increase economic value and income during a pandemic, in addition to boosting the economy in terms of nutritional content, sorghum has a nutritional content that is not inferior to the nutritional content of corn. The active components of functional food elements in corn kernels are relatively no different from sorghum seeds, as well as their health benefits (Suarni \& Yasin 2015), as a result of research by Schober et al. (2007); De Castro Palomino Siller (2007), informed that sorghum has the potential to be developed as a functional food because of its several chemical components. Sorghum has a lower gluten content and glycemic index (GI), making it very suitable for special nutritional diets.

\section{Conclusion}

Sorghum has an IC50 value of $88.8970 \mathrm{ppm}$, carbohydrate content of $71.8 \mathrm{~g}$, and protein content of $9.68 \%$. so that sorghum has the potential to develop functional food during the COVID-19 pandemic.

\section{References}

Andriani, A., \& Isnaini, M. (2013). Morfologi dan Fase Pertumbuhan Sorgum. Dalam; Sorgum Inovasi teknologi dan pengembangan. Penyunting Sumarno (et al.). Pusat Penelitian dan Pengembangan Tanaman Pangan.

Berenguer, M. J., \& Faci, J. M. (2001). Sorghum (Sorghum bicolor L. Moench) yield compensation processes under different plant densities and variable water supply. European Journal of Agronomy, 15(1), 43-55. https://doi.org/10.1016/S1161-0301(01)00095-8

De Castro Palomino Siller, A. (2007). In vitro starch digestibility and estimated glycemic index of sorghum products (Doctoral dissertation, Texas A\&M University).

Dewi, J. R., Estiasih, T., \& Murtini, E. S. (2012). Antioxidant Activity of Extracts Obtained by Applying Various Solvents to the Local Brown Sorghum (Sorghum bicolor) Bran. Jurnal Teknologi Pertanian, 8(3).

Dlamini, N. R., Taylor, J. R., \& Rooney, L. W. (2007). The effect of sorghum type and processing on the antioxidant properties of African sorghum-based foods. Food Chemistry, 105(4), 1412-1419. https://doi.org/10.1016/j.foodchem.2007.05.017

do Prado, M. E. A., Queiroz, V. A. V., da Veiga Correia, V. T., Neves, E. O., Roncheti, E. F. S., Gonçalves, A. C. A., ... \& de Oliveira, F. C. E. (2019). Physicochemical and sensorial characteristics of beef burgers with added tannin and tannin-free whole sorghum flours as isolated soy protein replacer. Meat science, 150, 93-100. https://doi.org/10.1016/j.meatsci.2018.12.006

Dykes, L., \& Rooney, L. W. (2006). Sorghum and millet phenols and antioxidants. Journal of cereal science, 44(3), 236-251. https://doi.org/10.1016/j.jcs.2006.06.007

Farré, I., \& Faci, J. M. (2006). Comparative response of maize (Zea mays L.) and sorghum (Sorghum bicolor L. Moench) to deficit irrigation in a Mediterranean environment. Agricultural water management, 83(1-2), 135-143. https://doi.org/10.1016/j.agwat.2005.11.001 
Luzardo-Ocampo, I., Ramírez-Jiménez, A. K., Cabrera-Ramírez, Á. H., Rodríguez-Castillo, N., Campos-Vega, R., Loarca-Piña, G., \& Gaytán-Martínez, M. (2020). Impact of cooking and nixtamalization on the bioaccessibility and antioxidant capacity of phenolic compounds from two sorghum varieties. Food chemistry, 309, 125684. https://doi.org/10.1016/j.foodchem.2019.125684

Molyneux, D. (2003). Lymphatic filariasis (elephantiasis) elimination: a public health success and development opportunity. Filaria journal, 2(1), 1-6.

Molyneux, P. (2004). The use of the stable free radical diphenylpicrylhydrazyl (DPPH) for estimating antioxidant activity. Songklanakarin J. sci. technol, 26(2), 211-219.

Moraes, É. A., da Silva Marineli, R., Lenquiste, S. A., Steel, C. J., de Menezes, C. B., Queiroz, V. A. V., \& Júnior, M. R. M. (2015). Sorghum flour fractions: Correlations among polysaccharides, phenolic compounds, antioxidant activity and glycemic index. Food chemistry, 180, 116-123. https://doi.org/10.1016/j.foodchem.2015.02.023

Mupangwa, W., Twomlow, S., \& Walker, S. (2012). Reduced tillage, mulching and rotational effects on maize (Zea mays L.), cowpea (Vigna unguiculata (Walp) L.) and sorghum (Sorghum bicolor L.(Moench)) yields under semiarid conditions. Field Crops Research, 132, 139-148. https://doi.org/10.1016/j.fcr.2012.02.020

Patel, P., \& Trivedi, R. (2016). Yield Performance of Calocybe indica on Different Agricultural Subatrate. International Research Journal of Engineering, IT and Scientific Research, 2(3), 66-71.

Santoso, I. A. (2011). Serat pangan (dietary fiber) dan manfaatnya bagi kesehatan. Magistra, 23(75), 35.

Schober, T. J., Bean, S. R., \& Boyle, D. L. (2007). Gluten-free sorghum bread improved by sourdough fermentation: biochemical, rheological, and microstructural background. Journal of Agricultural and Food Chemistry, 55(13), 5137-5146.

Sharanagat, V. S., Suhag, R., Anand, P., Deswal, G., Kumar, R., Chaudhary, A., ... \& Nema, P. K. (2019). Physicofunctional, thermo-pasting and antioxidant properties of microwave roasted sorghum [Sorghum bicolor (L.) Moench]. Journal of Cereal Science, 85, 111-119. https://doi.org/10.1016/j.jcs.2018.11.013

Sisein, E. A. (2014). Biochemistry of free radicals and antioxidants. Scholars Academic Journal of Biosciences, 2(2), $110-118$.

Suarni, S. (2016). Peranan sifat fisikokimia sorgum dalam diversifikasi pangan dan industri serta prospek pengembangannya. Jurnal Penelitian dan Pengembangan Pertanian, 35(3), 99-110.

Suarni, S., \& Yasin, M. (2015). Jagung sebagai sumber pangan fungsional. Iptek Tanaman Pangan, 6(1).

Sudarmadji, S., Suhardi, \& Haryono, B. (1989). Analisa bahan makanan dan pertanian. Liberty Yogyakarta bekerja sama dengan Pusat Antar Universitas Pangan dan Gizi Universitas Gadjah Mada.

Werdhasari, A. (2014). Peran antioksidan bagi kesehatan. Jurnal Biotek Medisiana Indonesia, 3(2), 59-68.

Winarsi, H. (2007). Antioksidan alami \& radikal bebas.

Wiwekowati, W., Astawa, P., Jawi, I. M., \& Sabir, A. (2017). Antioxidant activity of Apis mellifera sp. Propolis extract from Java (Indonesia). International Research Journal of Engineering, IT and Scientific Research, 3(5), $19-24$.

World Health Organization. (2020). Risk assessment and management of exposure of health care workers in the context of COVID-19: interim guidance, 19 March 2020 (No. WHO/2019-nCov/HCW_risk_assessment/2020.2). World Health Organization.

Yen, G. C., \& Chen, H. Y. (1995). Antioxidant activity of various tea extracts in relation to their antimutagenicity. Journal of agricultural and food chemistry, 43(1), 27-32.

Yousif, A., Nhepera, D., \& Johnson, S. (2012). Influence of sorghum flour addition on flat bread in vitro starch digestibility, antioxidant capacity and consumer acceptability. Food chemistry, 134(2), 880-887. https://doi.org/10.1016/j.foodchem.2012.02.199 